\title{
KEMAMPUAN MENGANALISIS PUISI "PAHLAWAN TAK DIKENAL" KARYA TOTO SUDARTO BACHTIAR DILIHAT DARI STRUKTUR FISIK DAN BATIN PESERTA DIDIK KELAS VIII I MTSN 2 BANJARMASIN
}

\author{
ABILITY TO ANALYZE THE POETRY "PAHLAWAN TAK DIKENAL" BY TOTO \\ SUDARTO BACHTIAR SEE FROM PHYSICAL AND INNER STRUCTURES \\ STUDENTS OF CLASS VIII I MTSN 2 BANJARMASIN
}

\author{
Annisa Yuniar Yasmin; Sainul Hermawan; Maria L.A.S. \\ Program Studi Pendidikan Bahasa dan Sastra Indonesia \\ FKIP Universitas Lambung Mangkurat \\ annisay73@yahoo.com
}

\begin{abstract}
Abstrak
Penelitian ini bertujuan untuk mendeskripsikan hasil kemampuan menganalisis puisi "Pahlawan Tak Dikenal" karya Toto Sudarto Bachtiar dilihat dari struktur fisik \& batin peserta didik kelas VIII I MTsN 2 Banjarmasin. Penelitian ini tergolong dalam jenis penelitian deskriptif kuantitatif karena kemampuan menganalisis puisi digambarkan dalam bentuk angka-angka. Dari gambaran dalam bentuk angka diketahui kemampuan peserta didik. Sumber data pada penelitian ini berjumlah 30 peserta didik. Instrumen dalam penelitian ini yaitu tes tertulis. Teknik pengumpulan data berupa observasi dan tes. Teknik analisis data berupa statistik deskriptif. Kemampuan peserta didik dalam menganalisis puisi masuk dalam kategori mampu. Nilai tertinggi dalam menganalisis, yaitu 97.5 sedangkan nilai terendah, 60. Dari hasil tes kemampuan tersebut, terdapat 28 orang yang masuk kategori mampu dan 2 orang yang masuk kategori tidak mampu.

Kata kunci: kemampuan menganalisis, puisi, struktur fisik dan batin
\end{abstract}

\begin{abstract}
This study aims to describe the results of the ability to analyze the poem "Pahlawan Tak Dikenal" by Toto Sudarto Bachtiar seen from the physical and inner structure of students in class VIII I MTsN 2 Banjarmasin. This research is classified as quantitative descriptive research because the ability to analyze poetry is described in the form of numbers. From the picture in the form of numbers, it is known the ability of students. The data sources in this study were 30 students. The instrument in this study is a written test. Data collection techniques in the form of observation and tests. The data analysis technique is descriptive statistics. The ability of students to analyze poetry is in the category of capable. The highest value in analyzing, namely 97.5 while the lowest value, 60. From the results of the ability test, there were 28 people who were in the capable category and 2 people who were in the category of incapable.
\end{abstract}

Keywords: analyzing ability, poetry, physical and mental structure 


\section{Pendahuluan}

Pengajaran sastra di sekolah menengah merupakan salah satu usaha untuk membina sikap baik manusia. Dari sastra, manusia bisa mengetahui kearifan budaya \& etika serta dapat lebih memahami kehidupan. Tujuan utama pengajaran sastra adalah untuk mencapai nilai apresiasi terhadap kreativitas sastra yang sudah dibuat serta memperoleh pengalaman sastra.

Dalam pengajaran sastra, apresiasi kreatif sangat diperlukan. Apresiasi kreatif dapat berupa respons sastra. Peserta didik dituntut untuk berpikir kritis dan mempunyai imajinasi yang luas agar ia bisa merespons suatu karya sastra secara imajinatif. Selain itu, peserta didik juga diharapkan mampu mempelajari beragam karya sastra.

Hakikatnya, pembelajaran sastra dalam dunia pendidikan dimasukkan ke dalam pelajaran bahasa Indonesia. Dengan belajar sastra, peserta didik dapat menanamkan rasa peka terhadap kehidupan, mengajarkan siswa bagaimana cara menghargai orang lain, mengerti hidup, \& belajar bagaimana menghadapi berbagai persoalan. Pendidik diharapkan dapat memotivasi peserta didik agar dapat meningkatkan minat baca, salah satunya minat baca terhadap sastra (Zulela dalam Sari, 2017:3).
Salah satu pembelajaran sastra di sekolah adalah pembelajaran puisi. Waluyo (1987:4) menjelaskan bahwa, puisi merupakan ungkapan kebahasaan yang menunjukkan kesatuan antara struktur kebahasaan \& struktur semantiknya.

Melalui puisi, peserta didik dapat mengapresiasikan atau menyampaikan perasaannya dengan berbagai imajinasi yang ia miliki. Di sekolah, peserta didik tidak diharapkan bisa membaca puisi saja, tetapi juga harus mampu memahami unsur-unsur pembangun puisi, yaitu struktur fisik puisi \& struktur batin puisi. Oleh karena itu, peserta didik perlu melakukan penganalisisan terhadap sebuah puisi.

Pembelajaran puisi di sekolah menengah kurang diminati oleh peserta didik (Mujahidin, 2012:130). Hal ini dapat terlihat secara nyata ketika peneliti melakukan pengamatan di tempat penelitian. Peserta didik merasa tidak tertarik untuk mengapresiasi puisi-puisi yang terdapat pada buku teks, bahkan ada yang merasa malu untuk membacakannya di depan kelas. Mereka merasa kesulitan ketika diberikan tugas menganalisis unsur pembangun puisi. Oleh karena itu, untuk membangun semangat peserta didik dalam mengikuti pembelajaran puisi, peran guru sangat diperlukan. Diperlukan kesabaran, 
bimbingan, \& latihan dalam mengarahkan peserta didik untuk memahami unsurunsur pembangun puisi serta menganalisis teks puisi. Peneliti mengajak peserta didik untuk mengapresiasi sebuah puisi yang tidak terdapat pada buku teks dengan cara menganalisis. Tentunya, peserta didik mempunyai berbagai macam karakteristik atau daya pikir yang berbeda-beda. Apabila apresiasi puisi disesuaikan dengan karakteristik peserta didik maka pembelajaran puisi akan lebih kreatif dan efektif. Dari situ, peneliti dapat melihat sejauh mana kemampuan peserta didik dalam menganalisis puisi.

Pada Kurikulum 2013 pada tingkatan kelas VIII, peserta didik diharapkanmampu menganalisis unsur pembangun puisi untuk mencapai indikator Kompetensi Dasar (KD) 3.8 Menelaah unsur-unsur pembangun teks puisi (perjuangan, lingkungan hidup, kondisi sosial, dan atau keberagaman budaya, dan lain-lain) yg diperdengarkan atau dibaca. Pembelajaran analisis teks puisi dapat melatih daya berpikir kritis peserta didik. Oleh karena itu, analisis unsur pembangun puisi merupakan kegiatan dari hasil pengamatan peserta didik mengenai teks puisi. Teks puisi yang dianalisis adalah puisi Pahlawan Tak Dikenal karya Toto Sudarto Bachtiar (tidak terdapat dalam buku teks). Pemilihan puisi tersebut dikarenakan peneliti ingin mengakrabkan kembali minat baca peserta didik terhadap karya sastra. Peneliti juga ingin mereka tidak monoton terhadap buku teks saja agar proses pembelajaran puisi di kelas tetap hidup. Oleh karena itu, peneliti memperkenalkan salah satu puisi sastrawan tersebut pada peserta didik untuk meningkatkan motivasi, minat, \& apresiasi mereka terhadap pembelajaran puisi.

Penelitian mengenai analisis puisi juga pernah diteliti oleh Marni pada 2016 dengan judul "Analisis Makna Intensi pada Puisi-puisi Penyair Pemula: Analisis Puisi Karya Siswa SMAN Agam Cendekia”, Azis Amin Mujahidin pada tahun 2012 dengan judul "Keefektifan Pembelajaran Apresiasi Puisi dengan Analisis Struktural dan Analisis Semiotik berdasarkan Gaya Berpikir SekuensialAcak pada Siswa SMP”, Sri Kurnia Hastuti Sebayang pada tahun 2010 dengan judul "Analisis Struktur Batin Puisi Sesamar Kasih Pencari Rezeki Karya Dwi Ayu Utami Nasution”.

Penelitian yang dibuat berbeda dengan penelitian sebelumnya. Penelitian yang dilakukan Silvia lebih fokus ke makna intensi pada puisi. Penelitian yang dilakukan oleh Azis fokus kepada pembelajaran apresiasi dan analisis puisi, dan penelitian yang dilakukan Sri Kurnia 
hanya berfokus pada analisis struktur batin puisi. Oleh karena itu, untuk menambah referensi \& mengkaji lebih dalam lagi penelitian mengenai analisis puisi, peneliti membedakan topik penelitian dari segi subjek penelitian, kelas, serta tempat penelitian. Berdasarkan uraian tersebut, hal ini sangat penting untuk meneliti "Kemampuan Menganalisis Puisi "Pahlawan Tak Dikenal" Karya Toto Sudarto Bachtiar Dilihat dari Struktur Fisik dan Batin Peserta Didik Kelas VIII I MTsN 2 Banjarmasin".

\section{Metode Penelitian}

Desain penelitian yang digunakan yaitu deskriptif kuantitatif. Data berupa hasil kerja analisis puisi yang dilakukan peserta didik kelas VIII I MTsN 2 Banjarmasin. Sumber data pada penelitian ini merupakan peserta didik kelas VIII I. Instrumen yang digunakan adalah tes tertulis. Teknik pengumpulan data ada dua yaitu, observasi \& tes. Teknik analisis data menggunakan analisis statistik deskriptif dengan rumus rata-rata hitung (arithmetic mean)

\section{Hasil dan Pembahasan}

Hasil penelitian ini merupakan hasil tes yg berupa data kuantitatif, yang menggambarkan tentang kemampuan menganalisis teks puisi pada aspek tipografi, diksi, kata konkret, pengimajian, majas, rima, nada dan suasana, tema, perasaan, amanat.

Data yang diperoleh dalam penelitian ini dianalisis sesuai dengan teknik analisis yang tlah dijelaskan pada bab sebelumnya yaitu statistik deskriptif menggunakan rumus rata-rata hitung (arithmetic mean)

$$
\dot{X}=\frac{X 1+X 2+X 3+\ldots X n}{n}
$$

(Subagyo : 28).

Berikut hasil tes menganalisis puisi "Pahlawan Tak Dikenal" karya Toto Sudarto Bachtiar dilihat dari struktur fisik dan batin peserta didik kelas VIII I MTsN 2 Banjarmasin.

Gambar 1. Hasil Tes Kemampuan Menganalisis Puisi "Pahlawan Tak Dikenal" karya Toto Sudarto Bachtiar Peserta Didik kelas VIII I MTsN 2 Banjarmasin

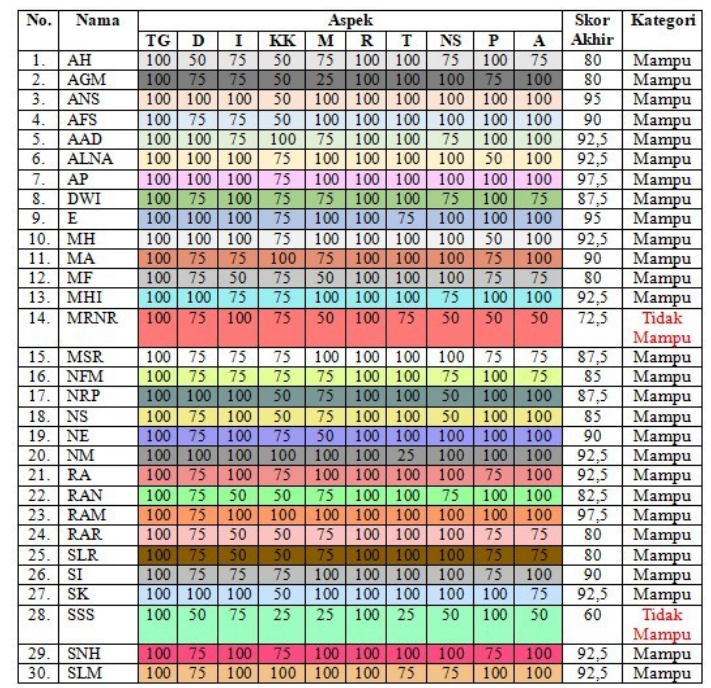

Keterangan:

TG : Tipografi

D : Diksi

I : Pengimajian / Imaji 
KK : Kata Konkret

M : Majas

$\mathrm{R}$ : Rima

$\mathrm{T}$ : Tema

NS : Nada dan Suasana

$\mathrm{P}$ : Perasaan

A : Amanat

Berdasarkan tabel hasil tes di atas, penilaian tiap aspek dapat diketahui. Kemampuan peserta didik dalam mengalanisis puisi masuk dalam kategori mampu. Nilai tertinggi dalam menganalisis, yaitu 97,5 sedangkan nilai terendah yaitu 60 . Nilai 97,5 diperoleh 2 orang, nilai 95 diperoleh 2 orang, nilai 92,5 diperoleh 9 orang, nilai 90 diperoleh 4 orang, nilai 87,5 diperoleh 3 orang, nilai 85 diperoleh 2 orang, nilai 82,5 diperoleh 1 orang, nilai 80 diperoleh 5 orang, nilai 72,5 diperoleh 1 orang, dan nilai 60 diperoleh 1 orang. Dari uraian di atas dapat disimpulkan menjadi tabel di bawah ini.

Tabel 1. Kategori penilaian

\begin{tabular}{|l|l|l|l|}
\hline $\begin{array}{l}\text { Nila } \\
\text { i }\end{array}$ & $\begin{array}{l}\text { Kategor } \\
\text { i }\end{array}$ & $\begin{array}{l}\text { Frekuens } \\
\text { i }\end{array}$ & $\begin{array}{l}\text { Persentas } \\
\text { e }\end{array}$ \\
\hline$>75$ & Mampu & 28 & $93 \%$ \\
\hline$<75$ & $\begin{array}{l}\text { Tidak } \\
\text { Mampu }\end{array}$ & 2 & $7 \%$ \\
\hline \multicolumn{2}{|l|}{ Jumlah } & 30 & $100 \%$ \\
\hline
\end{tabular}

Pengelompokan tingkat kemampuan peserta didik menganalisis unsur pembangun puisi kategori mampu atau tidak mampu didasarkan pada acuan yang dikemukakan dlam dokumen MTsN 2 Banjarmasin "Kriteria Ketuntasan Minimal (KKM) MTsN 2 Banjarmasin Tahun 2018/2019", yaitu:

a. Seorang peserta didik dikatakan mampu menganalisis unsur pembangun puisi jika nilai yang diperoleh minimal 75 .

b. Seorang peserta didik dikatakan tidak mampu menganalisis unsur pembangun puisi jika nilai tidak mencapai 75 .

Berdasarkan tabel kategori penilaian di atas, hasil tes kemampuan menganalisis puisi "Pahlawan Tak Dikenal" karya Toto Sudarto Bachtiar peserta didik kelas VIII I MTsN 2 Banjarmasin terdapat 28 peserta didik yang dikategorikan mampu \& 2 peserta didik yang dikategorikan tidak mampu.

Hasil analisis data di atas menunjukkan bahwa semua peserta didik mengetahui pembelajaran mengenai analisis unsur pembangun puisi. Seluruh peserta didik menggunakan 10 aspek unsur pembangun puisi, yaitu tipografi, diksi, imaji, kata konkret, majas, rima, tema, nada dan suasana, perasaan, dan amanat. Namun, ada beberapa peserta didik yang belum menguasai 10 aspek tersebut. Terbukti, mereka masih kurang jelas mendeskripsikan aspek-aspek dalam puisi yang sudah ditentukan. 
Hasil dari kemampuan menganalisis puisi pada aspek tipografi, semua peserta didik mampu menggambarkan perwajahan puisi dengan jelas. Pada aspek tipografi diperlukan kejelasan dalam menggambarkan perwajahan puisi, agar puisi dapat dipahami dengan mudah. Kemampuan peserta didik dalam menganalisis puisi pada aspek tipografi sudah sangat sesuai dengan isi puisi.

Hasil dari kemampuan menganalisis puisi pada aspek diksi, ada 10 peserta didik yg sangat sesuai, 18 peserta didik yang sesuai, dan 2 peserta didik yang kurang sesuai mendeskripsikan pilihan kata dengan isi puisi. Pada aspek diksi diperlukan ketepatan kata dalam menggambarkan isi puisi, agar puisi dapat dipahami dengan mudah. Dengan demikian, kemampuan menganalisis puisi pada aspek diksi masih perlu ditingkatkan.

Hasil dari kemampuan menganalisis puisi pada aspek imaji, ada 16 peserta didik yg sangat sesuai, 9 peserta didik yang sesuai, dan 5 peserta didik yang kurang sesuai mendeskripsikan pengimajian dengan isi puisi. Pada aspek imaji diperlukan citraan yang jelas dalam menggambarkan isi puisi, agar puisi lebih menarik. Dengan demikian, kemampuan menganalisis puisi pada aspek imaji masih perlu ditingkatkan.

Hasil dari kemampuan menganalisis puisi pada aspek kata konkret, ada 5 peserta didik yang sangat sesuai, 15 peserta didik yang sesuai, 9 peserta didik yang kurang sesuai, dan 1 peserta didik yang tidak sesuai mendeskripsikan pilihan kata dengan isi puisi. Pada aspek kata konkret diperlukan kesesuaian makna dalam menggambarkan isi puisi, agar makna puisi dapat tersampaikan. Dengan demikian, kemampuan menganalisis puisi pada aspek kata konkret masih perlu ditingkatkan.

Hasil dari kemampuan menganalisis puisi pada aspek majas, ada 15 peserta didik yang sangat sesuai, 10 peserta didik yang sesuai, 3 peserta didik yang kurang sesuai, dan 2 peserta didik yang tidak sesuai menggambarkan gaya bahasa dengan isi puisi. Pada aspek majas diperlukan kejelasan dalam menggambarkan isi puisi agar puisi lebih menarik.

Hasil dari kemampuan menganalisis puisi pada aspek rima, semua peserta didik mampu menggambarkan dengan jelas. Pada aspek rima diperlukan ketepatan dalam menggambarkan pengulangan bunyi puisi, agar puisi lebih menarik. Kemampuan peserta didik dalam menganalisis puisi pada aspek rima sudah sangat sesuai dengan isi puisi.

Hasil dari kemampuan menganalisis puisi pada aspek tema, ada 25 peserta didik yang sangat sesuai, 3 peserta didik yang sesuai, dan 2 peserta didik yang tidak sesuai dalam menyampaikan tema dengan 
isi puisi. Pada aspek tema diperlukan ketepatan gagasan pokok yang menggambarkan isi puisi.

Hasil dari kemampuan menganalisis puisi pada aspek nada dan suasana, ada 19 peserta didik yang sangat sesuai, 7 peserta didik yang sesuai, dan 4 peserta didik yang kurang sesuai dalam menggambarkan perasaan yang terdapat pada puisi. Pada aspek nada dan suasana diperlukan penggambaran sikap yang jelas dalam menentukan nada dan suasana yang terdapat pada puisi.

Hasil dari kemampuan menganalisis puisi pada aspek nada dan suasana, ada 18 peserta didik yang sangat sesuai, 9 peserta didik yang sesuai, \& 3 peserta didik yang kurang sesuai dalam menggambarkan perasaan yang terdapat pada puisi. Pada aspek perasaan diperlukan ungkapan yang dirasakan penyair dalam menggambarkan isi puisi.

Hasil dari kemampuan menganalisis puisi pada aspek amanat, ada 20 peserta didik yang sangat sesuai, 8 peserta didik yang sesuai, dan 2 peserta didik yang kurang sesuai dalam menentukan amanat yang terdapat pada puisi. Pada aspek amanat, diperlukan kejelasan dalam menentukan pesan yang terkandung dan ingin disampaikan langsung kepada para pembaca.

Dari hasil analisis data di atas, semua peserta didik mampu memahami materi unsur pembangun puisi, yaitu tipografi, rima, tema, dan amanat. Sedangkan unsur yang lainnya, ada yg menguasai dan ada yang belum menguasai. Dari hasil akhir tes, diperoleh 28 peserta didik yang mampu dan 2 peserta didik yang tidak mampu dalam menganalisis puisi. Seperti yang dikatakan oleh Waluyo (1987:145), bahwa langkah-langkah pemahaman sebuah puisi sebenarnya adalah mampu memahami unsur-unsur pembangun puisi, yakni struktur fisik dan struktur batin puisi. Peran guru sangat diperlukan di sini untuk membimbing peserta didik dalam menguasai pembelajaran analisis puisi.

\section{Simpulan dan Saran}

\section{Simpulan}

Berdasarkan hasil penelitian dapat disimpulkan bahwa, pelajaran Bahasa Indonesia di MTsN 2 Banjarmasin memiliki Kriteria Ketuntasan Minimal (KKM) nilai 75. Peserta didik yang mendapat nilai di atas 75 dikategorikan mampu, sedangkan yang mendapat nilai di bawah 75 dikategorikan tidak mampu. Terdapat 28 peserta didik dikategorikan mampu dan 2 peserta didik dikategorikan tidak mampu. Nilai tertinggi diperoleh peserta didik dalam menganalisis teks puisi adalah 97.5 sedangkan nilai terendah, yaitu 60. 
Saran

Bagi guru atau pengajar, diharapkan pembelajaran bisa menyesuaikan dengan Rencana Pelaksanaan Pembelajaran (RPP) agar tujuan pembelajaran tercapai. Lebih bisa menguasai kelas serta harus lebih sabar dalam melatih dan membimbing peserta didik agar mereka lebih bisa menguasai materi pembelajaran. Diperlukan inovasi-inovasi baru bagi pengajar dalam melaksanakan proses pembelajaran agar peserta didik lebih semangat dalam mengikuti pembelajaran. Bagi siswa, diharapkan lebih giat belajar dan sering berlatih untuk mengembangkan keahlian yang dimiliki dan jika belum memahami suatu pelajaran lebih baik ditanyakan kepada guru agar lebih mengerti dan menguasai materi pembelajaran.

\section{Daftar Pustaka}

Daryanto. 2014. Penelitian Tindakan Kelas dan Penelitian Tindakan Sekolah. Yogyakarta: Gava Media.

Matheus, Marlond. "Kemampuan Siswa Kelas X SMA Cinta Budaya Menganalisis Teks Negosiasi Tahun Pembelajaran 2017/2018." Dalam jurnal publikasi daring.
Mujahidin, Azis Amin. 2012. "Keefektifan Pembelajaran Apresiasi Puisi dengan Analisis Struktural dan Analisis Semiotik berdasarkan Gaya Berpikir Sekuensial-Acak pada Siswa SMP." Dalam jurnal Seloka Vol. 2, No. 1. Publikasi daring. Universitas Negeri Semarang.

Pradopo, Rahmat Djoko. 1987. Pengkajian Puisi. Yogyakarta: Gajah Mada University Press.

Rahmanto. 2007. "Pembelajaran Apresiasi Puisi di Sekolah Menengah Atas." Dalam jurnal SintesisVol. 5, No. 2. Publikasi daring. Universitas Sanata Dharma.

Sari, Riski Puspita. 2015. "Kemampuan Mengidentifikasi Unsur Intrinsik Cerpen Siswa Kelas XI SMA Negeri 1 Semparuk." Dalam jurnal Pendidikan Bahasa Indonesia. Publikasi daring. FKIP Untan Pontianak.

Sari, Rizqi Ratna Artika. 2017. "Kajian Struktur Puisi Karya Siswa Kelas V SDN Mrican 4 Kota Kediri Tahun Pelajaran 2016/2017." Dalam jurnal Simki-PedagogiaVol. 1, No. 6. Publikasi daring. Universitas Nusantara PGRI Kediri.

Subagyo, Pangestu. 1992. Statistik Deskriptif. Yogyakarta: BPFE.

Sugiyono. 2011. Metode Penelitian Kuantitatif, Kualitatif, dan $R \& D$.Bandung: Alfabeta.

Waluyo, Herman J. 1987. Teori dan Apresiasi Puisi. Jakarta: Erlangga. 
